\title{
THE CHROMIAN MARBLES OF KITTILÄ, FINNISH LAPLAND
}

\author{
YRJÖ PEKKALA and KAUKO PUUSTINEN
}

\begin{abstract}
PEKKALA, YRJÖ and PUUSTINEN, KAUKO 1978: The chromian marbles of Kittilä, Finnish Lapland. Bull. Geol. Soc. Finland 50: $15-29$.

The volcano-sedimentary rock association at Kittilä is characterized in many places by the presence of green-colored fuchsite-bearing ferroan dolomite-quartz rocks, locally called chromian marbles. The rock is cut by coarse-grained quartz-breunnerite veins. The surrounding country rock is a carbonate rock in which fuchsite has been replaced by chlorite or sericite. As the amount of the carbonates decreases, the rock grades into a quartz-sericite rock and eventually into a chlorite schist. These carbonate rocks have originated as chert-carbonate sediments.

Yrjö Pekkala, Geological Survey of Finland, SF-02150 Espoo 15, Finland.

Kauko Puustinen, Geological Survey of Finland, SF-96101 Rovaniemi 10, Finland.
\end{abstract}

\section{Introduction}

The investigated area is located about 130 $\mathrm{km}$ north of Rovaniemi (Fig. 1) and some 15 $\mathrm{km}$ east-northeast of the village of Kittilä in Finnish Lapland.

This paper describes the brightly greencolored carbonate rocks that have been found in the Kittilä region. Owing to the presence of chromian muscovite (fuchsite), the rocks are called chromian marbles. Some of the marble deposits have been investigated for building stone purposes (Pekkala 1972).

The chromian marbles were first mentioned by Hackman (1927). In his extensive description of the geology of central Lapland somewhat later, Mikkola (1941, p. 215) re- garded these rocks as associated with the greenstones in Kittilä. Independently of chromian marble investigation an other exploration program was recently carried out concerning the Riikonkoski copper ore deposit, situated some $10 \mathrm{~km}$ northeast of the village of Kittilä (Yletyinen and Nenonen 1972, Nenonen 1975, Nurmi 1975). The papers mentioned give detailed descriptions of the geology of the Kittilä region.

The main physiographic feature of the area is a comparatively flat central Lapland plain, interrupted in a few places by hilly terrain and fells. The area is covered by transported Quaternary deposits, underlain by an in situ weathered crust which grades downwards into a hard bedrock. Outcrops 


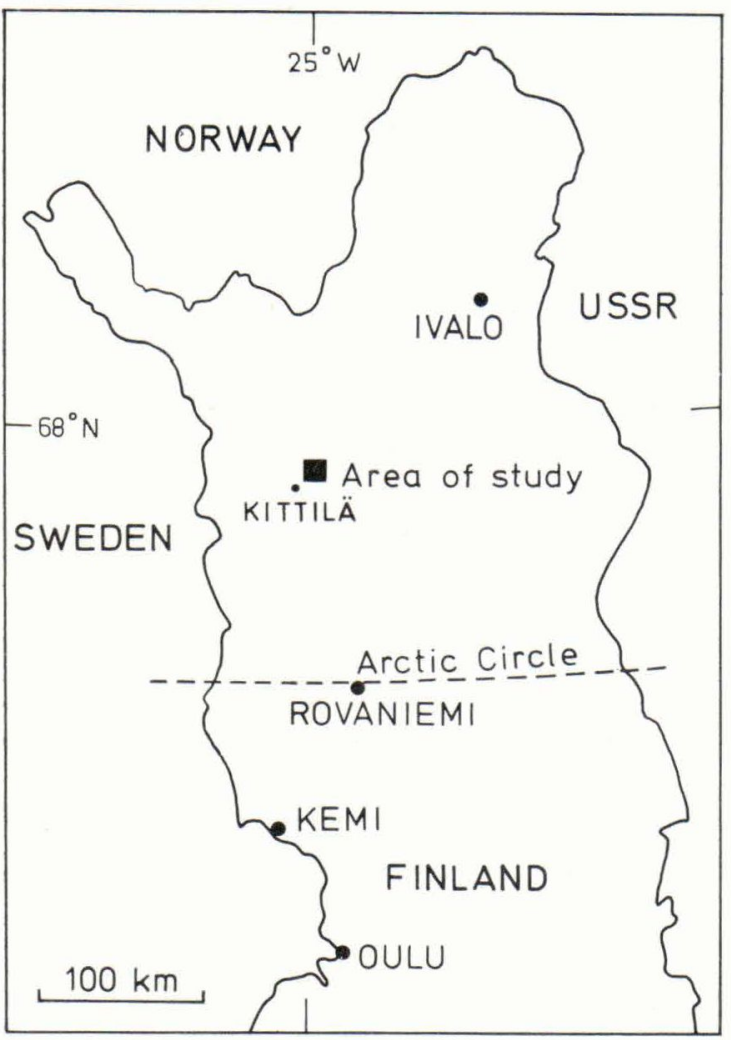

Fig. 1. Location of the study area in Kittilä.

are generally scarce, mainly due to the extensive low-lying peatland.

\section{General geology}

The chromian marbles are encountered in the south-western parts of the extensive Kittilä spilitic greenstone formation, in the west-northwest trending central Lapland schist belt. Towards the south the belt is bordered by the large granite province of northern Finland (Mikkola 1941).

The investigated area is characterized by stratigraphically overlapping heterogeneous sedimentary and volcano-sedimentary formations (Fig. 2). All solid rock is Precambrian in age and the regional metamorphic grade is generally low (greenschist facies), with primary textures well preserved in many places.

The oldest portion of the bedrock consists of a chlorite-bearing mica schist and phyllite, with occasional very thin dolomite intercalations. The phyllite is recognized by the presence of graphite and small amounts of sulphides. Most of the material in these rocks has originated from clayic and sapropelic sediments.

Contemporaneously with the above sedimentation, volcanic activity started in the north and east of the present area. Many of the flows are pillowed, indicating, together with the evidence of interflow sedimentation, that much of this spilitic volcanism in Kittilä took place in a marine environment. The main constituents of the mafic lavas are amphibole, chlorite, albite and biotite, with lesser amounts of epidote and carbonate. Agglomerates and tuffs are frequent among the greenstones, too.

Keratophyre and quartz keratophyre represent the acid differentiates of this volcanism. The group also includes lapilli tuffs and epiclastic volcanic tuffs (albite-quartz rock). Quartz-sericite schist is in most parts a tuffaceous rock, originating from a chemically weathered and reworked keratophyric material.

Chlorite-carbonate, biotite-carbonate, sericite-carbonate and fuchsite-bearing carbonate rocks are associated with the greenstones in many places.

The intrusive rocks of the area are structurally conformable diabase and gabbro sills and lenses between the sedimentary and greenstone beds. In many cases the intrusive bodies are differentiated: amphibole-chlorite rock, albite gabbro, albite-biotite rock and albite-quartz rock (albitite), the most acid member. Radiometric age determinations of zircon from these albite diabases show an 


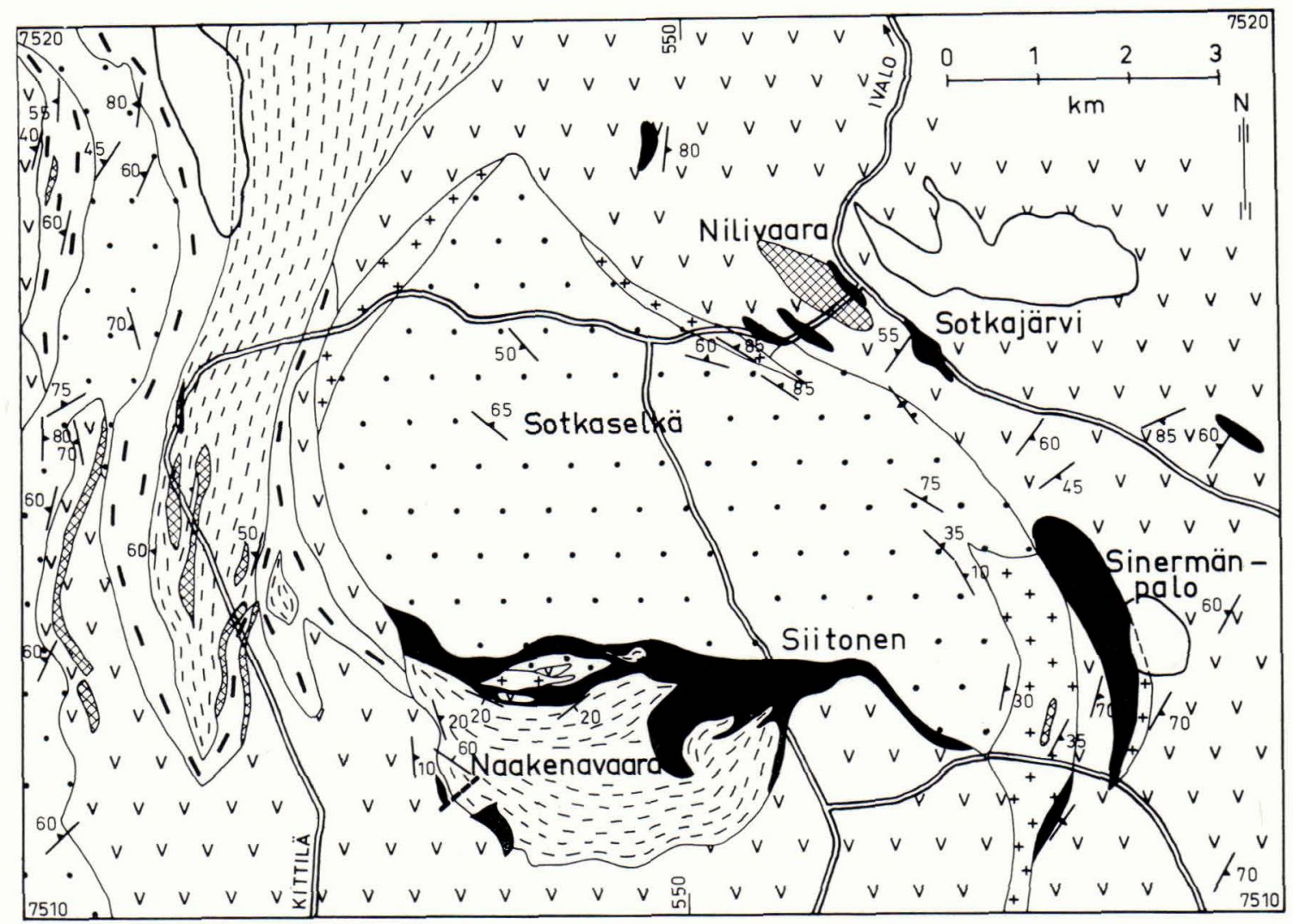

\begin{tabular}{|c|c|c|c|}
\hline$\because \because$ & Kumpu-quartzite & x & Albite diab \\
\hline-- & Greywacke & +++ & Keratophyre \\
\hline $\bar{E}=-$ & Phyllite & $v_{v} v$ & Greenstone \\
\hline & Carbonate rocks & $7^{30}$ & Schisto \\
\hline
\end{tabular}

Fig. 2. Geological map of the Sotkaselkä area, Kittilä (after Nenonen 1975). The dashed line at Naakenavaara shows the location of the cross section of Fig. 5.

age of 2050 m.y. (Geological Survey of Finland 1972).

As the volcanic activity ceased, erosion started above the sea level, providing material for younger greywacke.

The above sequence overlain, in part with a marked angular unconformity, by rocks of Kumpu-series (Mikkola 1941, p. 181). These are represented by the Sotkaselkä quartzite in the central part and by conglomerates in the western part of the area mapped in Fig. 2.

\section{Chromian marble occurrences}

This paper describes four of the investigated chromian marble occurrences in the 

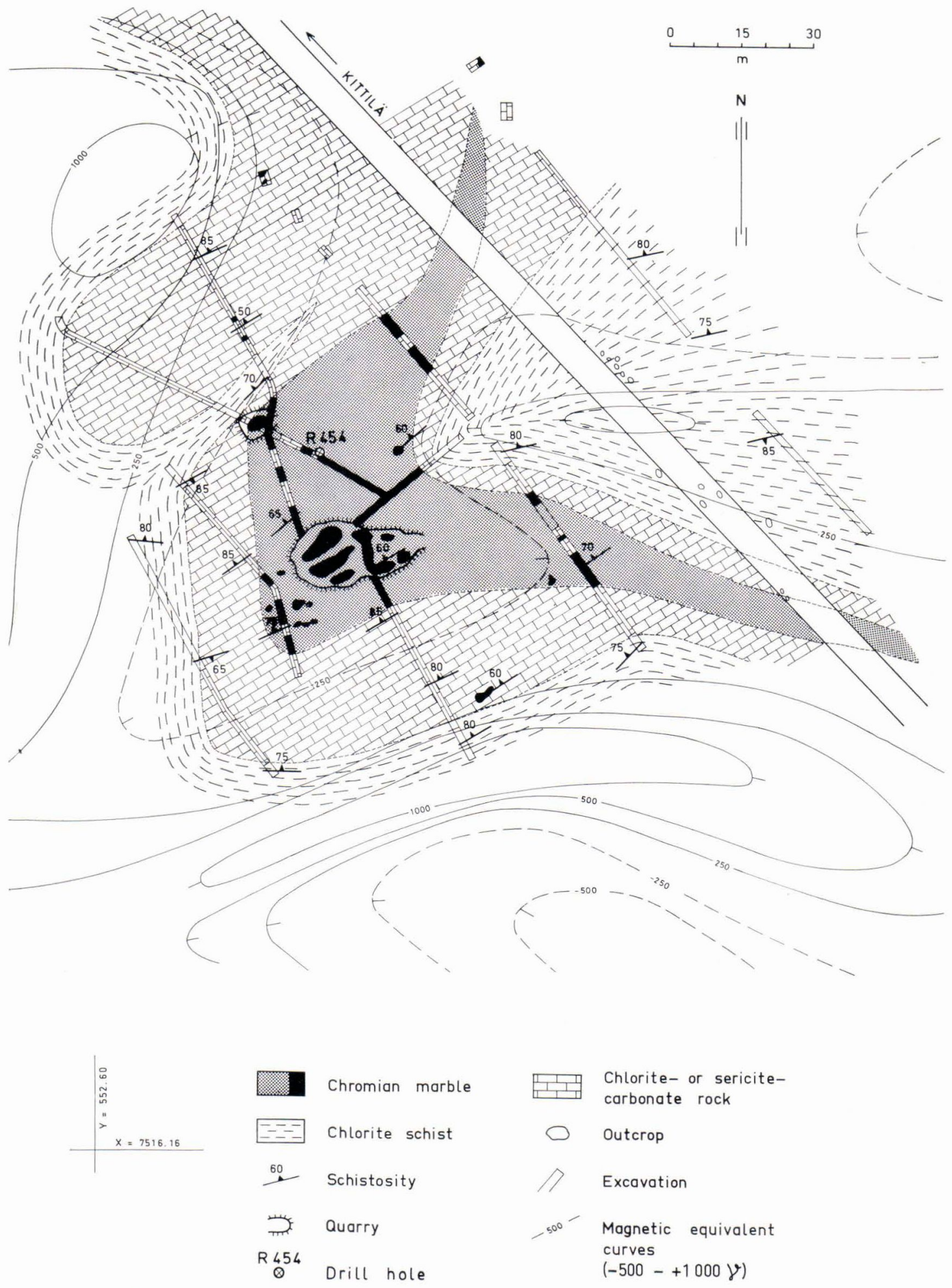

Fig. 3. Geological map of the chromian marble occurrence at Sotkajärvi. 

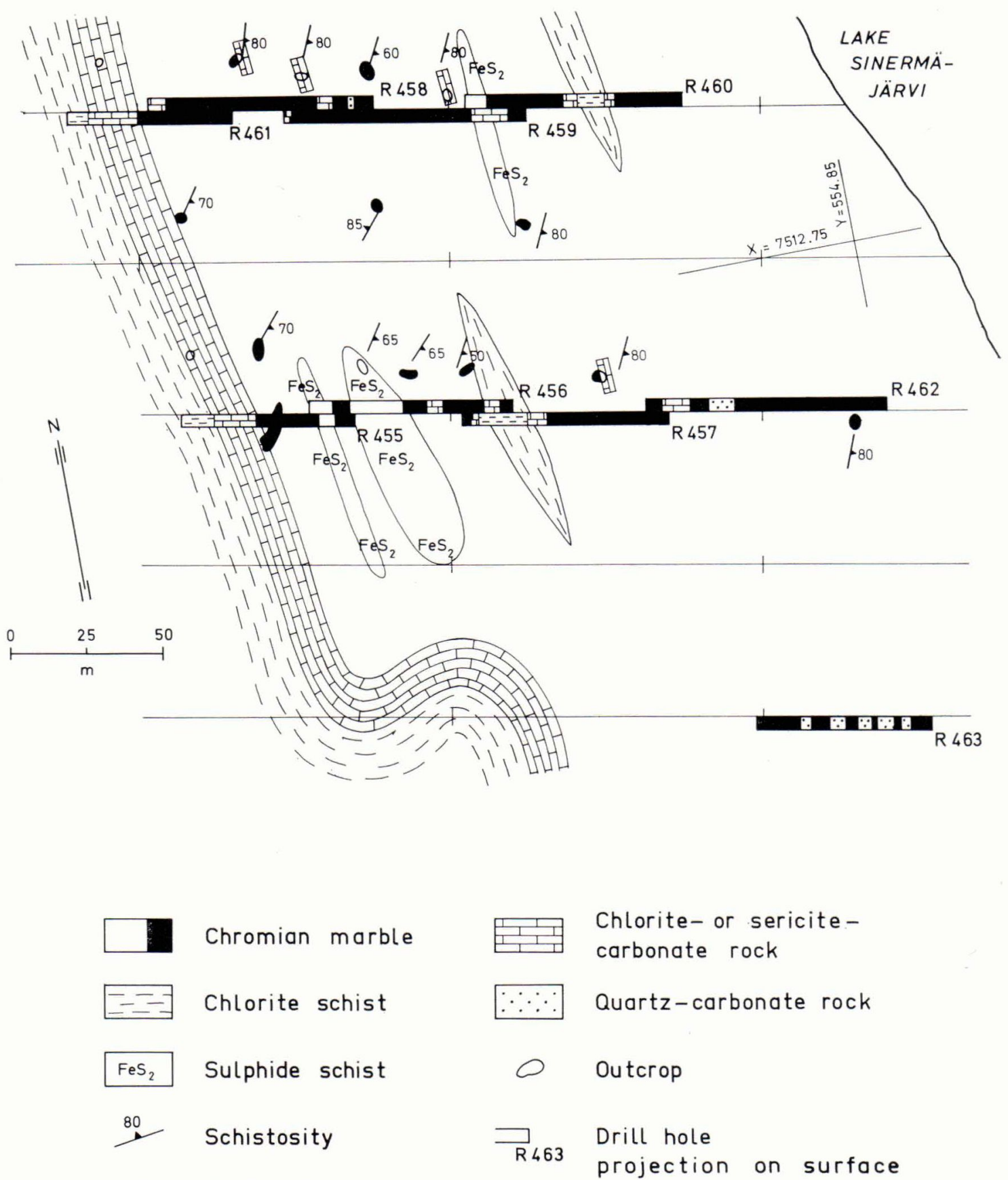

Fig. 4. Geological map of the chromian marble occurrence at Sinermänpalo.

Kittilä region: Sotkajärvi, Sinermänpalo, Siitonen and Naakenavaara (see Fig. 2).

Sotkajärvi. The structure of the Sotkajärvi area is characterized by a strong folding, which is clearly revealed by field magnetic measurements. Excavations and diamond drillings show the chromian marble to be located at the top of a fold, where it reaches 
a thickness of $20-25 \mathrm{~m}$ (Fig. 3). In the limbs of the fold it is divided into several gradually thinning layers. The country rock is a chlorite- and sericite-bearing carbonate rock, which grades into a chlorite schist on both sides of the carbonate rocks. The revealed rock sequence, from the chromian marble to the chlorite schist, reaches a total thickness of up to $60 \mathrm{~m}$.

Sinermänpalo. In the north-south aligned carbonate-rich zone to the west of Lake Sinermäjärvi, a body of carbonate rocks over $1000 \mathrm{~m}$ long and over $200 \mathrm{~m}$ wide has been proved. The main part of this Sinermänpalo occurrence is composed of chromian marble (Fig. 4). In its present position it has s steep eastern dip. The body is underlain by a chlorite schist with a marginal zone of chlorite-bearing carbonate rock up to $15 \mathrm{~m}$ thick. In the chromian marble itself, there are layers in which fuchsite has been replaced by sericite or chlorite. Intercalations of chlorite schist, quartz-carbonate rock and further on, bed-like lenses of sulphide-rich schist are also met.
In the upper part of the chromian marble deposit, sericite-quartz-carbonate rock and quartz-carbonate rock intercalations are frequent. By inference from the easternmost drillholes and from a single outcrop to the south of the lake, the overlying country rock is a quartz-carbonate rock.

Siitonen. A lense-shaped carbonate rock occurrence up to $50 \mathrm{~m}$ thick and about $150 \mathrm{~m}$ long has been proved in the Siitonen carbonate-rich zone on the basis of field magnetic measurements and diamond drillings. The central part is compsed of a layer of chromian marble up to $20 \mathrm{~m}$ thick. The country rock next to it is a carbonate rock in which fuchsite has been replaced by sericite. As the amount of carbonates decreases, the rock grades into a quartzsericite schist. This schist lies on both sides of the carbonate rock body and is overlain by the Sotkaselkä quartzite. Magnetic measurements suggest that the carbonate rock and the quartz-sericite schist are underlain by a chlorite schist.

Naakenavaara. The Naakenavaara area is

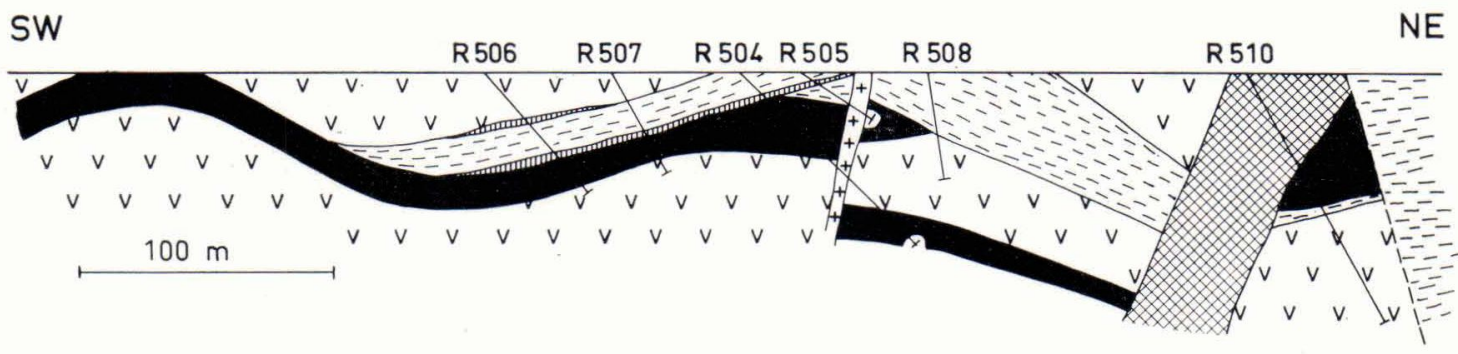

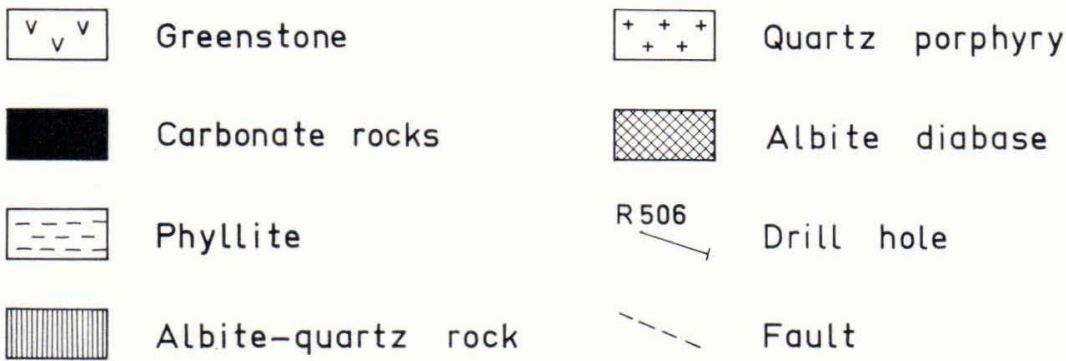

Fig. 5. A cross section through the southwestern part of the Naakenavaara area. 
characterized by a gently sloping anticline in which the bedding is almost horizontal. The complex rock sequence from bottom to top is: greenstones; an assemblage of alternating beds of carbonate-rich rocks, phyllite, quartz-sericite schist, albite-quartz rock, greenstone; and quartzite of the Kumpuseries. Dikes of gabbroic metadiabase, quartz keratophyre and quartz porphyry cut the sequence below the quartzite. Copper mineralizations have been found mainly in connection with the quartz-sericite schist and phyllite. The geochemical exploration in Naakenavaara has been treated by Nenonen and Puustinen (1976) and they found that the glacial till and weathered rocks on the carbonate rock horizon are enriched in copper and nickel.

At Naakenavaara, the chromian marble occurs as unhomogeneous layers, from a few centimeters to 30 meters thick in a stratabound carbonate-rich horizon made up of sericite-carbonate, chlorite-carbonate and biotite-carbonate rocks. The horizon is overlain and underlain by various rocks, such as quartz-sericite schist, phyllite, albite-quartz rock, chlorite schist and greenstone. The general position of the Naakenavaara carbonate rocks is different from he other chromian marble occurrences, owing to the complexity of the rock sequence and as well as to the composition of the mafic minerals. Fig. 5 shows a cross section through the southwestern part of the area.

\section{Petrography}

Chromian marble. The chromian marble is a bright green, usually a very fine-grained (0.02-0.2 $\mathrm{mm})$ carbonate rock, containing on an average $60 \%$ carbonates, $25 \%$ quartz, $15 \%$ fuchsite and $2 \%$ pyrite. Albite and tourmaline occur as accessory minerals. Grains of chromite were also found in thin sections from the Sotkajärvi occurrence.

Owing to the parallel mica-surfaces and schlierens the rock is clearly foliated. In large scale, the mica-surface are discontinuous and clearly bent in many places. Coarse-grained

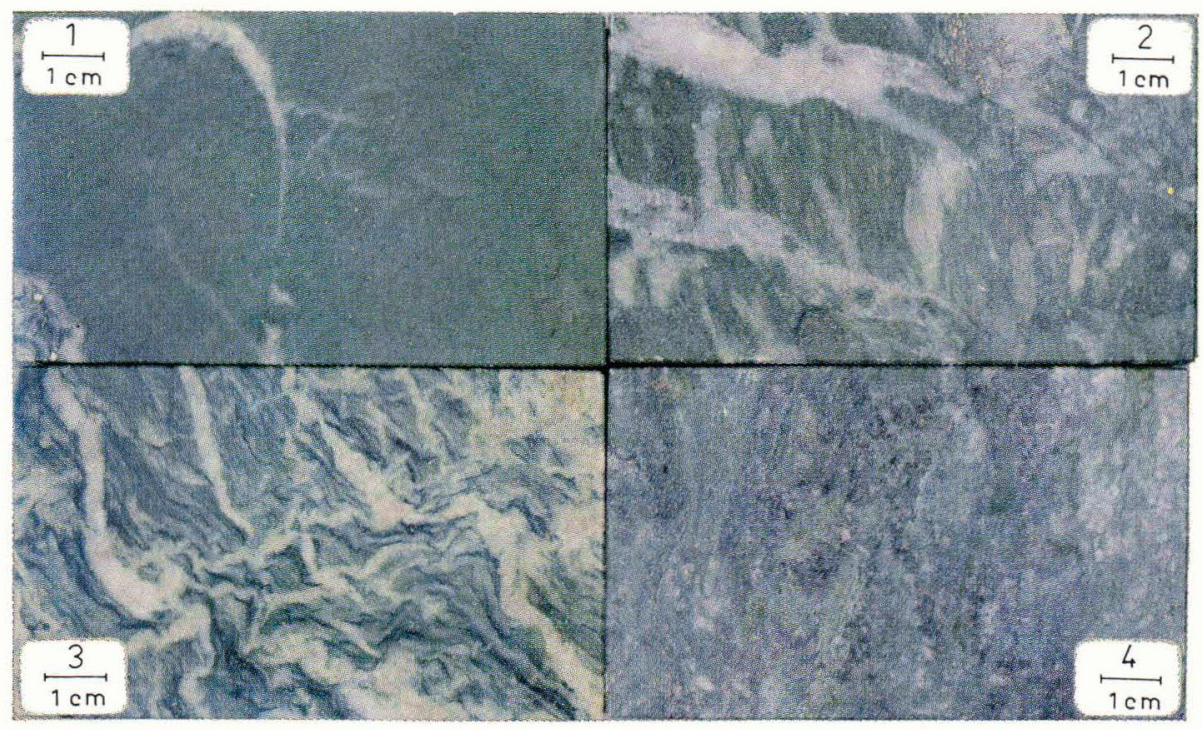

Fig. 6. Different types of chromian marbles. For the explanation see text. 
quartz-carbonate veins frequently cut the chromian marble, giving rise to a very heterogeneous appearance.

Different types of chromian marbles are shown in Fig. 6. The most common types are 1 and 3. Sometimes the first variation is even more homogeneous than in the picture, especially when the quartz-carbonate veins are missing. Type 3 is very heterogeneous, owing to the light color of the carbonates and the highly bent mica- and carbonate-rich layers. The dark color of types 2 and 4 derives mainly from the carbonates and partly from a small amount of chlorite.

In general the rock is strongly deformed and recrystallized; alternating carbonate, quartz and mica layers can be seen in some places, however. These layers are believed to be derived from the original bedding, especially the very fine-grained, clearly stratified quartz (chert) layers, in which the stratified texture is caused by numerous micro-grained sulphide bands.

Chlorite and sericite carbonate rock. In general the country rock surrounding the chromian marble is a carbonate rock in which fuchsite has been replaced by chlorite or sericite. The average content of the rock is $50 \%$ carbonates, $20 \%$ quartz, $20 \%$ chlorite or $15 \%$ sericite and $2 \%$ pyrite; sometimes grains of albite also occur.

The grain size of the rock is from $0.03 \mathrm{~mm}$ to $0.2 \mathrm{~mm}$ and color greenish or pale gray. Quartz-carbonate veins are not as frequent as in the chromian marble, so that the rock has a relatively homogeneous appearance. The veins have a grain size of $0.05-1 \mathrm{~mm}$.

Chlorite schist. The chlorite schist contains on an average $25 \%$ chlorite (sometimes up to $60 \%$ ), $25 \%$ carbonates, $25 \%$ sericite (or talc), $15 \%$ albite, $2 \%$ quartz (sometimes up to $10 \%$ and about $5 \%$ opaque minerals, mainly pyrite. In some places it also contains up to $3 \%$ biotite.

The rock is very fine-grained $(0.01-0.1$ $\mathrm{mm}$ ), clearly foliated and its color is greenish black or dark grey. The carbonate minerals occur as relatively large idiomorphic grains or in carbonate veins.

The main part of white mica is composed of sericite, but farther away from the chromian marble the amount of talc increases and, at the same time, the amount of quartz decreases.

Quartz-sericite schist. In some places the country rock surrounding the chromian marble and sericite carbonate rock is a quartz-sericite schist, which contains on an average $50 \%$ sericite, $40 \%$ quartz, $10 \%$ carbonates, $2 \%$ pyrite and sometimes a few grains of albite.

The schist is very fine-grained $(0.01-0.2$ $\mathrm{mm}$ ) and clearly foliated. The quartz is partly micro-grained $(0.01 \mathrm{~mm})$ chert-quartz and partly it is fine-grained $(0.05-0.1 \mathrm{~mm})$. These quartz grains are surrounded by sericite and carbonate, and the rock appears clastic in texture. Yet the texture most probably is not clastic because sericite and carbonate also occur as inclusions in quartz, indicating that the quartz grains obtained their form in their present environment.

Quartz-carbonate rock. The drill cores from the upper parts of the Sinermänpalo deposit, near the western shore of Lake Sinermäjärvi contain intercalations of quartz-rich rock. The average mineral composition is $80 \%$ quartz, $10 \%$ carbonates, $2 \%$ albite, $5 \%$ pyrite and $3 \%$ sericite. The main part of the rock is made up of a very fine-grained chert-quartz, intersected by coarse-grained quartz-carbonate-albite veins.

Sulphide schist. In general the chromian marble has an extensive sulphide impregnation. In some places, the sulphide content rises as high as $30 \%$, in which case the rock is called a sulphide schist.

At Sinermänpalo there are several bedlike sulphide schist lenses, which are up to $20 \mathrm{~m}$ thick and $60 \mathrm{~m}$ long. The mineral 
composition varies: in general it is $50 \%$ quartz, $25 \%$ carbonates, $20 \%$ pyrite, $5 \%$ sericite and some albite. The typical sulphide schist is a very fine-grained quartzose schist, with the quartz bands (beds) and partly sulphidezed carbonate bands alternating.

\section{Mineralogy}

Carbonates. A characteristic feature of the investigated chromian marbles is a thick, rusty crust on the weathered surface of the rock. Out of doors a fresh surface acquires a clearly rusty shade within a year, and after three to five years the marble has a deeply rusted weathering surface. This tendency to rust is mainly due to the carbonate minerals present in the chromian marble. The carbonates occur in two different modes: in the fine-grained matrix with quartz and mica, and in the coarse-grained quartz-carbonate veins.

Initial investigation of carbonates by staining methods showed the main carbonate mineral to be dolomite, with some coarsegrained iron-rich carbonate. The main cations, $\mathrm{Ca}, \mathrm{Mg}, \mathrm{Fe}$ and $\mathrm{Mn}$ of thirteen dolomites and nine iron-rich carbonates from Sinermänpalo were analyzed by microprobe. The same samples were also pulverized and investigated by X-ray diffractometer. Also,

Table 1. Chemical composition of ferroan dolomites from Sinermänpalo, Kittilä. Electron microprobe analyses by Tuula Paasivirta, expressed in wt. $\%$ with calculated mol. $\%$ of carbonates. The CO values are calculated from cation amounts, n.d.=not determined.

\begin{tabular}{|c|c|c|c|c|c|c|c|c|c|c|}
\hline No. & Drill hole depth & $\mathrm{FeO}$ & $\mathrm{MnO}$ & $\mathrm{MgO}$ & $\mathrm{CaO}$ & $\mathrm{CO}_{2}$ & $\mathrm{FeCO}_{3}$ & $\mathrm{MnCO}_{3}$ & $\mathrm{MgCO}_{3}$ & $\mathrm{CaCO}_{3}$ \\
\hline 1 & $R 455-43.60$ & 4.1 & 1.0 & 17.8 & 29.8 & 45.76 & 5.5 & 1.3 & 42.2 & 51.0 \\
\hline 2 & $\mathrm{R} 455-12.60$ & 4.5 & 0.7 & 17.3 & 31.0 & 46.22 & 6.0 & 0.9 & 40.6 & 52.5 \\
\hline 3 & $\mathrm{R} 455-12.60$ & 4.2 & 0.6 & 17.6 & 30.6 & 45.98 & 5.5 & 0.8 & 41.5 & 52.2 \\
\hline 4 & $\mathrm{R} 456-58.70$ & 5.2 & 0.6 & 18.6 & 31.8 & 48.83 & 6.5 & 0.7 & 41.8 & 51.0 \\
\hline 5 & $\mathrm{R} 456-58.70$ & 5.2 & 0.7 & 18.6 & 31.4 & 48.36 & 6.5 & 0.9 & 41.7 & 50.9 \\
\hline 6 & $\mathrm{R} 457-48.50$ & 4.2 & 1.1 & 18.3 & 31.1 & 47.45 & 5.3 & 1.4 & 41.9 & 51.4 \\
\hline 7 & $\mathrm{R} 457-48.50$ & 4.5 & 1.2 & 18.1 & 31.2 & 47.56 & 5.8 & 1.6 & 41.3 & 51.4 \\
\hline 8 & $\mathrm{R} 457-48.50$ & 5.6 & 1.2 & 16.7 & 30.4 & 46.07 & 7.4 & 1.6 & 39.3 & 51.7 \\
\hline 9 & R462-25.95 & 4.1 & 0.2 & 18.5 & 31.3 & 47.20 & 5.3 & 0.3 & 42.5 & 51.9 \\
\hline 10 & $\mathrm{R} 462-25.95$ & 4.2 & 0.3 & 18.4 & 31.0 & 46.99 & 5.4 & 0.4 & 42.5 & 51.7 \\
\hline 11 & $\mathrm{R} 462-45.65$ & 6.6 & 0.3 & 17.1 & 31.7 & 47.59 & 8.5 & 0.4 & 39.0 & 52.2 \\
\hline 12 & $\mathrm{R} 462-45.65$ & 5.9 & n.d. & 18.1 & n.d. & - & - & - & - & - \\
\hline 13 & $\mathrm{R} 463-9.35$ & 4.6 & 0.6 & 17.9 & 31.0 & 46.87 & 6.0 & 0.7 & 41.5 & 51.7 \\
\hline
\end{tabular}

Table 2. Chemical composition of breunnerites from Sinermänpalo, Kittilä. Electron microprobe analyses by Tuula Paasivirta, expressed in wt. $\%$ with calculated mol. $\%$ of carbonates. The $\mathrm{CO}_{2}$ values are calculated from cation amounts.

\begin{tabular}{|c|c|c|c|c|c|c|c|c|c|c|}
\hline No. & Drill hole depth & $\mathrm{FeO}$ & $\mathrm{MnO}$ & $\mathrm{MgO}$ & $\mathrm{CaO}$ & $\mathrm{CO}_{2}$ & $\mathrm{FeCO}_{3}$ & $\mathrm{MnCO}_{3}$ & $\mathrm{MgCO}_{3}$ & $\mathrm{CaCO}_{3}$ \\
\hline 1 & $\mathrm{R} 456-58.70$ & 25.6 & 1.2 & 24.2 & 1.5 & 43.91 & 35.6 & 1.7 & 60.0 & 2.7 \\
\hline 2 & $\mathrm{R} 456-58.70$ & 25.2 & 1.1 & 23.4 & 1.7 & 42.89 & 35.9 & 1.5 & 59.5 & 3.1 \\
\hline 3 & $\mathrm{R} 456-58.70$ & 25.6 & 1.3 & 24.7 & 0.9 & 44.05 & 35.5 & 1.8 & 61.1 & 1.6 \\
\hline 4 & $R 462-25.95$ & 15.3 & 0.5 & 34.6 & 0.6 & 47.82 & 19.7 & 0.6 & 79.4 & 0.2 \\
\hline 5 & $R 462-25.95$ & 21.7 & 0.5 & 28.6 & 0.1 & 44.80 & 29.6 & 0.7 & 69.5 & 0.2 \\
\hline 6 & R462-25.95 & 21.1 & 0.5 & 29.0 & 0.3 & 45.02 & 28.6 & 0.7 & 70.2 & 0.5 \\
\hline 7 & $R 463-9.35$ & 19.0 & 0.6 & 32.5 & 0.1 & 47.47 & 24.4 & 0.7 & 74.6 & 0.2 \\
\hline 8 & $R 463-9.35$ & 19.7 & 0.6 & 32.0 & 0.1 & 47.35 & 25.4 & 0.7 & 73.6 & 0.2 \\
\hline 9 & $R 463-9.35$ & 22.5 & 0.9 & 29.3 & 0.3 & 46.46 & 29.6 & 1.2 & 68.7 & 0.5 \\
\hline
\end{tabular}


four dolomites and four iron-rich carbonates from Siitonen were investigated by X-ray diffractometer.

The results of the microprobe analyses with calculated mol. $\%$ of carbonates are presented in Tables 1 and 2. According to this data the ratios of $\mathrm{Mg}$ and $\mathrm{Fe}$ components vary between 4.6 and 8.0 in the dolomites and between 1.7 and 4.0 in the iron-rich carbonates. The X-ray determinations of the same samples gave $\mathrm{Mg} / \mathrm{Fe}$ ratios between 5.7 and 9.0 for the dolomites, and between 1.2 and 2.3 for the iron-rich carbonates. X-ray determinations of the samples from the Siitonen occurrence gave $\mathrm{Mg} / \mathrm{Fe}$ ratios between 3.0 and 9.0 for dolomites, and between 0.7 and 3.0 for iron-rich carbonates.

If more than $20 \%$ of the magnesium in the dolomite lattice has been replaced by ferrous iron $(\mathrm{Mg} / \mathrm{Fe}<4)$, the carbonate is ankerite (Deer et al. 1962, p. 278). According to this definition, the main carbonate mineral in the chromian marble is a ferroan dolomite, and sometimes it may contain just enough ferrous iron to be called an ankerite. A magnesite containing $5-50 \mathrm{~mol} . \quad \% \quad \mathrm{FeCO}_{3}$ is called breunnerite, while a siderite containing $30-$ $50 \% \mathrm{MgCO}_{3}$ is called pistomesite (Deer et al. 1962 , p. 257 and 273). Accordingly, the ironrich carbonate in the chromian marble is in most cases breunnerite, and in a few cases pistomesite.

In conclusion it can be said that the main carbonate mineral in the chromian marble is a ferroan dolomite, and sometimes ankerite. The carbonate mineral occurring for the most part only in the coarse-grained quartzcarbonate veins with ferroan dolomites is in its composition almost half way between magnesite and siderite. Mostly it is breunnerite and in a few cases pistomesite. Calcite was met with on a few occasions, as tiny grains in the chlorite-bearing carbonate rock.
Table 3. Chemical composition (wt. $\%$ ) and atomic ratios based on 22 anions of fuchsites from Kittilä. Electron microprobe analyses by Tuula Paasivirta.

\begin{tabular}{|c|c|c|c|}
\hline & 1. & 2. & 3. \\
\hline $\mathrm{SiO}_{2}$ & 46.1 & 45.0 & 44.8 \\
\hline $\mathrm{TiO}_{2}$ & 0.3 & 0.1 & 0.2 \\
\hline $\mathrm{Al}_{2} \mathrm{O}_{3}$ & 30.9 & 34.4 & 35.2 \\
\hline $\mathrm{Cr}_{2} \mathrm{O}_{3}$ & 2.7 & 1.2 & 1.1 \\
\hline $\mathrm{FeO} *)$ & 3.1 & 3.1 & 3.2 \\
\hline $\mathrm{MnO}$ & 0.0 & 0.0 & 0.0 \\
\hline $\mathrm{MgO}$ & 3.1 & 1.3 & 1.6 \\
\hline $\mathrm{CaO}$ & 0.0 & 0.0 & 0.0 \\
\hline $\mathrm{Na}_{2} \mathrm{O}$ & tr. & tr. & tr. \\
\hline \multirow[t]{2}{*}{$\mathrm{K}_{2} \mathrm{O}$} & 10.7 & 10.5 & 10.7 \\
\hline & 96.9 & 95.6 & 96.8 \\
\hline \multicolumn{4}{|c|}{ *) total iron } \\
\hline $\mathrm{Si}$ & 6.2 & 6.1 & 5.9 \\
\hline $\mathrm{Al}^{[4]}$ & 1.8 & 1.9 & 2.1 \\
\hline $\mathrm{Al}[6]$ & 3.1 & 3.6 & 3.4 \\
\hline $\mathrm{Cr}$ & 0.3 & 0.1 & 0.1 \\
\hline $\mathrm{Fe}^{2+}$ & 0.4 & 0.3 & 0.4 \\
\hline $\mathrm{Mg}$ & 0.6 & 0.3 & 0.3 \\
\hline $\mathrm{K}$ & 1.8 & 1.8 & 1.8 \\
\hline$\Sigma \mathrm{Z}$ & 8.0 & 8.0 & 8.0 \\
\hline$\Sigma Y$ & 4.4 & 4.3 & 4.2 \\
\hline$\Sigma x$ & 1.8 & 1.8 & 1.8 \\
\hline
\end{tabular}

1. Fuchsite, Sinermänpalo (R455-12.60)

2. Fuchsite, Siitonen (R451-39.60)

3. Fuchsite, Siitonen(R451-39.60)

Fuchsite. Fuchsite occurs as bright green thin schlierens or, where the schistosity of the rock is not very conspicuous, as evenly distributed flakes. In thin section it is found as particles $0.02 \mathrm{~mm}$ in breadth and up to 0.1 $\mathrm{mm}$ long, which form stripes up to $0.5 \mathrm{~mm}$ wide among the other minerals. In a thin section the pleochroic colors are unexpectedly light-colored: $\mathrm{X}=$ almost colorless and $\mathrm{Y}, \mathrm{Z}=$ very light greenish. Therefore it is very difficult to distinguish a fuchsite from muscovite without a macroscopic examination.

The chemical analyses of fuchsites from Sinermänpalo and Siitonen are presented in Table 3 . The analytical values are in agreement with those of other chromian muscovites in the literature (Whitmore et al. 1946). Analyses of other minerals in the marbles 
Table 4. Partial chemical analyses (ppm, Fe: wt. \%) of different rock-types from the Sinermänpalo and Naakenavaara areas. $\mathrm{N}=$ number of analyses. XRF analyses ( $\mathrm{Fe}, \mathrm{Mn}, \mathrm{Cr}, \mathrm{Sr}$ and $\mathrm{Ba}$ ) by Väinö Hoffrén and emission spectrometer analyses ( $\mathrm{Ti}$ and $\mathrm{Ni}$ ) by Gustav Wansén.

\begin{tabular}{|c|c|c|c|c|c|c|}
\hline & $\begin{array}{l}\text { Chromian } \\
\text { marble }\end{array}$ & $\begin{array}{l}\text { Chlorite } \\
\text { and } \\
\text { sericite } \\
\text { carbonate } \\
\text { rock }\end{array}$ & $\begin{array}{l}\text { Chlorite } \\
\text { schist }\end{array}$ & $\begin{array}{l}\text { Kerato- } \\
\text { phyre }\end{array}$ & $\begin{array}{l}\text { Green- } \\
\text { stone }\end{array}$ & Quartzite \\
\hline \multicolumn{7}{|l|}{$\mathrm{Fe}$} \\
\hline Mean & 8.2 & 8.9 & 8.3 & 6.1 & 8.8 & 3.7 \\
\hline Range & $4.4-12.4$ & $4.7-15.3$ & $4.7-10.7$ & $0.9-13.0$ & $4.7-13.9$ & $1.4-8.0$ \\
\hline \multicolumn{7}{|c|}{$\mathrm{Mn}$} \\
\hline Mean & 2710 & 2420 & 2210 & 1220 & 1290 & 130 \\
\hline Range & $1400-4600$ & $800-4400$ & $1800-4400$ & $100-4100$ & $400-2800$ & $0-300$ \\
\hline \multicolumn{7}{|l|}{$\mathrm{Ti}$} \\
\hline Mean & 2920 & 1970 & 2450 & 6220 & 5490 & 3700 \\
\hline Range & $1590-5360$ & $830-3630$ & $1270-6050$ & $1310-9570$ & $950-10770$ & $2300-4990$ \\
\hline \multicolumn{7}{|c|}{$\mathrm{Cr}$} \\
\hline Mean & 2640 & 2970 & 2410 & 230 & 190 & 280 \\
\hline \multirow{2}{*}{\multicolumn{7}{|c|}{$\mathrm{Sr}$}} \\
\hline & & & & & & \\
\hline Mean & 110 & 100 & 140 & 20 & 10 & - \\
\hline Range & $0-240$ & $0-630$ & $0-460$ & $0-60$ & $0-50$ & - \\
\hline \multicolumn{7}{|l|}{$\mathrm{Ba}$} \\
\hline Mean & 210 & 80 & 220 & 60 & 80 & 300 \\
\hline Range & $0-1000$ & $0-600$ & $0-900$ & $0-500$ & $0-300$ & $200-400$ \\
\hline \multicolumn{7}{|c|}{$\mathrm{Ni}$} \\
\hline Mean & 530 & 840 & 870 & 40 & 50 & 40 \\
\hline Range & $10-1110$ & $20-1400$ & $110-1340$ & $0-120$ & $0-90$ & $10-70$ \\
\hline $\mathrm{N}$ & 31 & 18 & 7 & 9 & 7 & 4 \\
\hline
\end{tabular}

show $\mathrm{Cr}_{2} \mathrm{O}_{3}$ contents of up to 0.6 in biotite and $0.4-1.0 \%$ in chlorite.

\section{Geochemistry of the chromian marble and the adjoining rocks}

The partial analyses of the chromian marbles and the adjoining country rocks are summarized in Table 4, where the arithmetic means and ranges of concentrations for each element are given. The analyzed samples are from the chromian marble occurrences of Sinermänpalo (39 samples) and Naakenavaara (37 samples), which were investigated in detail by diamond drillings. The samples were taken at 5-10 meter intervals through the two occurrences. In the samples analyzed the chlorite-carbonate rock includes also the sericite-rock and occasional talc-bearing rock verieties.

The rock types presented in Table 4, can be divided into three groups: 1 . chromian marble and other carbonate-bearing rocks, including also the chlorite schist, 2. keratophyre and greenstone and 3. quartzite of the Kumpu-series.

The rocks of the first group are all similar in their analyzed chemical components, but differ from the others, especially in their $\mathrm{Ti}, \mathrm{Mn}$ and $\mathrm{Cr}$ contents; the $\mathrm{Sr}, \mathrm{Ba}$ and $\mathrm{Ni}$ contents are also a distinguishing feature. The second group has different $\mathrm{Fe}, \mathrm{Mn}$ and Ti contents than the third group.

In general the iron content of the Kittilä carbonate rocks is noticeably higher than that of ordinary sedimentary carbonate rocks which are composed mainly of calcite and dolomite (Wolf et al. 1967). The contents of $\mathrm{Sr}$ and $\mathrm{Ba}$ are usual for sedimentary carbonate rocks. The contents of $\mathrm{Mn}$ and $\mathrm{Ti}$ are distinctly higher than the average values, but within the ranges found for sedimentary 
carbonate rocks. The content of $\mathrm{Cr}$ which is somewhat higher than the maximum value (2000 ppm) given by Wolf et al. (1967), is presumably a regional peculiarity. The high chromium content was also noted by Ohlson (1969), who found nickel and chromium to occur is conspicuous amounts in almost all rock samples he examined in the nearby Loukinen area in Kittilä.

In ten random samples of sulphide-bearing schists from the Sinermänpalo marble occurrence, the $\mathrm{Au}$ content is as much as 0.5 ppm and the Ag content $3 \mathrm{ppm}$ (Nenonen 1975). The $\mathrm{Ni}$ and $\mathrm{Co}$ contents of the same samples are as much as $0.33 \% \mathrm{Ni}$ and $0,11 \%$ $\mathrm{Co}$, respectively. The $\mathrm{Ni}$ and $\mathrm{Co}$ are concentrated in a mineral belonging to the linnaeite-group and the Co also in pyrite. For the sake of comparison it may be noted that the gold content of the quartz-carbonate rocks associated with the gold ore in the Kerr Addison Mine is $0.021 \mathrm{ppm}$ (Tihor and Crocket 1977), and that of the gold deposits of Witwatersrand about $10 \mathrm{ppm}$ (Pretorius 1976), making the Kittilä marbles possible targets for gold prospecting.

\section{Discussion}

Fuchsite has been encountered in various mineral and rock associations and environments. The classification of Whitmore et al. (1946) has been modified for use in the present paper. Accordingly, the fuchsite occurrences are considered as four associations, of which the first is by far the most common: 1. with carbonates (ankerite), quartz, sulphides and gold, 2. with biotite or actinolite in amphibolite (Tufar 1968), 3. with corundum and kyanite in hornblendite (Partridge 1937), and 4. quartzose rocks (Clifford 1956, Hackman 1927). Other associations include fuchsite in chromite ore, pegmatites, greenschists and silicified dolomites.

The fuchsite association with carbonates, quartz, sulphides and gold includes the volcano-sedimentary rock environment, comprising for instance the highly metalliferous Abitibi greenstone belt in Canada (Kirkland-Larder Lakes area: Ridler 1970, 1972; Tihor and Crocket 1975); the Outokumpu-type copper ore deposits in Finland (Eskola 1933 and Huhma 1976); the Kittilä area in the present study; and possibly also the Mother Lode deposits in California (Knopf 1929).

The following modes have been proposed for the origin of the fuchsite-bearing carbonate rocks: 1 magmatic, 2 . metasomatic and 3 . sedimentary.

1. The relatively high carbonate content of greenstones has been discussed by many authors. In some cases the carbonate rocks occur so abundantly as to give rise to independent rock units. The examination of the rocks from Glarus in Switzerland, summarized by Amstutz and Patwardhan (1974), shows that the carbonate-rich rocks were formed in and with the final hydromagmatic or hypothermal crystallization fractionating of spilitic rocks. In many papers Amstutz €ven refers to these as »carbonatites».

According to Whitmore et al. (1946) most of the constituents, and particularly the chromium of the fuchsite occurrences, have had their origin in solutions derived from the same siliceous magmatic source. In many cases the carbonate zones appear spatially related to intrusive quartz porphyries.

In describing the carbonate rocks adjoining the Kittilä greenstones, Mikkola (1941, p. 215) notes that sthe carbonates adjoining the greenstones are not original sediments, but rather volcanic products, being especially well comparable with the albite rocks in their mode of occurrence». About the albite rocks Mikkola (p. 253) says, "that entire formation of these rocks is duly to be explained by the extreme concentration of highly aqueous late magmatic solutions charged with carbon 
dioxide, of which the crystallization occurred at at very low temperatures».

Paakkola (1971) proposes that the carbonates of the albite-carbonate rocks of central Lapland are juvenile and the carbonates could not be products of assimilation of carbonate-rich sediments by a greenstone magma. Piispanen (1972) is of the opinion that the carbonate-rich rocks of the spilite association in western Kuusamo, northeastern Finland, are products of magmatic differentiation, but the magma is rich in carbonates because it has assimilated carbonate-rich sediments through which it penetrated on its way to the geosyncline.

The above descriptions suggest that at least part of the Kittilä carbonate rocks could be of magmatic origin. However, as will be discussed later, this is not the case for the main part of the material in the chromian marble and the adjoining carbonate rocks.

2. Ohlson (1969) describes ultramafic talcmagnesite schist bodies in the bedrock of Loukinen-Nilivaara area, which overlaps the present study area in the north. On the basis of their mode of occurrence and geochemistry, he is also of the opinion that the fuchsite-bearing carbonate rocks bear a closer relationship to the talc-carbonate schists than to the greenstones. The present authors, on the other hand, have found that in the Nilivaara-Sinermäjärvi area the rock at the contact zone between the chromian marble and the carbonate and talc-bearing chlorite schists, always contains plenty of quartz and, further, the quartz content of the chromian marble is very high. This makes it difficult to believe that the chromian marble would be a metasomatic product after an ultramafic rock. Moreover, the talc-magnesite rocks adjoining several serpentinites within 30 kilometers of the investigated area are very different from the talc-carbonate-chlorite schists located near the chromian marble occurrences.
Tihor and Crocket (1977) have proposed that most of the green quartz-carbonate rocks from the Larder Lake area originate from altered ultramafics.

3. The chromian marble occurrences of the study area are located in the same stratigraphic horizon, in the uppermost part of the Kittilä volcano-sedimentary rock association, and not far from the lowest part of the quartzites of Kumpu-series.

In consideration of the stratigraphic position of the chromian marble, its contact relations with the country rocks, the mineralogical and chemical composition, and the preserved sedimentary features, the authors propose that the chromian marble occurrences in Kittilä are of sedimentary origin.

The sedimentation occurred under the carbonate-facies conditions in a restricted basin. The chemical composition of the carbonates together with the abundant sulphide impregnation suggest that the Eh conditions were reducing. In some place the conditions reached those of the sulphidefacies and caused the sedimentation of sulphides. Alternating with the carbonate sedimentation, large amounts of chert were deposited.

In fact, the sedimentation conditions responsible for the formation of the chromian marble were not markedly different from those for Precambrian chert-siderite iron ores such as found in Porkonen-Pahtavaara, some $15 \mathrm{~km}$ to the east of the present area. The amount of iron available at the time of formation of the carbonate sediments (89 wt. $\%$ ) was not high enough for the deposition of a true iron formation, however.

The material for the chert-carbonate sediments presumably derived in part from the chemical weathering of pre-existing rocks and in part from direct volcanic activity in the geosyncline and the surrounding area. The amount of sedimentary material derived from the last source was quite small, how- 
$\epsilon$ ver, because at least $\mathrm{Mg}$ is notably rare in volcanic emanations, as shown by White and Waring (1963). The anomalously high $\mathrm{Cr}$ content in the carbonate sediments indicates that ultrabasic rocks, typically high in chromium, were present in the weathering area.

On the basis of the chemical analyses, the chromian marble and the adjoining rocks could be divided into three groups. The chemical differences suggest the different origin of the three groups, while the chemical similarity of the chromian marble and its adjacent country rocks points to a closely related origin. The contents of analyzed elements are almost the same in the rock series from the fuchsite-bearing marble to the chlorite schist, even though their mineral compositions are different. This is possible if the rocks were closely connected in origin and each element was available in equal amounts. The material was probably fed into the geosyncline as bicarbonates and hydrolysates. Clay minerals have played a considerable part only in the deposition of the chlorite schist. The sediments did not acquire their final chemical composition until during the diagenesis, however.

In this connection it may be noted that the marble occurrences in Kittilä are very similar in mineralogy, texture and stratigraphic position to the gold-bearing carbonate occurrences of the KirklandLarder Lakes area in Ontario (Ridler 1970, 1972; Tihor and Crocket 1975). The Precambrian (Upper Archean) carbonate rocks occur there in a definite stratigraphic horizon in a volcano-sedimentary sequence and carbonate rocks are mainly composed of dolomite, magnesite and quartz, with lesser amounts of fuchsite, chlorite and pyrite. According to Ridler (1972 and 1976) these rocks are carbonate-facies exhalites (chemical sediments of volcanic origin).

\section{Summary}

The present authors propose that the chromian marble and its adjacent country rocks in Kittilä originated as chertcarbonate sediments. The minerals acquired their chemical composition during the diagenesis and consolidation of the rocks. In this stage all »free» $\mathrm{Fe}$ and $\mathrm{Cr}$ hydrolysates were fixed into available minerals: $\mathrm{Cr}$, for instance, into sericite to form fuchsite.

During the regional metamorphism, folding and deformation, the chromian marble was for the most part recrystallized, partly remobilized and pressed into the tops of the folds. The rock was also foliated and numerous quartz-carbonate veins were formed. This new carbonaté generation was coarsegrained and composed partly of ferroan dolomite and partly of breunnerite.

In the final stage the straight-lined quartzcarbonate veins formed, intersecting all other textural features of the chromian marble.

Acknowledgements - The authors are indebted to Miss Tuula Paasivirta, M.Sc., for microprobe analyses; to Mr Pekka Kallio, M. Sc., for X-ray determinations; to Mrs Helena Murtovaara for drawing the illustrations; to Mr Erkki Halme for taking the photograph; and to Mrs Kay Ahonen for checking the language of the English manuscript. Special thanks are to Dr. Atso Vorma for critically reading the paper.

\section{References}

Amstutz, G. C. and Patwardhan, A. M. (1974) A reappraisal of the textures and the composition of the spilites in the Permo-Carboni- ferous Verrucano of Glarus, Switzerland. Pp. 71-81 in Spilites and spilitic rocks; ed. by

G. C. Amstutz. Springer-Verlag, Berlin. 
Clifford, Tom N. (1957) Fuchsite from a Silurian quartz conglomerate, Ackworth Township, New Hampshire. Am. Min. 42: 566-568.

Deer, W. A., Howie, R. A. and Zussman, J. (1962) Rock-forming minerals, vol. 5 (non-silicates). Longmans, Green and Co. Ltd., London.

Eskola, Pentti (1933) On the chrome minerals of Outokumpu, C. R. Soc. Géol. Finlande 7: 2644.

Eskola, Pentti (1963) The Precambrian of Finland. Pp. 145-263 in The Precambrian, vol. 1; ed. by K. Rankama. Interscience Publishers, New York.

Geological Survey of Finland (1972). Annual Report.

Hackman, V. (1927) Studien über den Gesteinsaufbau der Kittilä-Lappmark. Bull. Comm. Géol. Finlande 79.

Huhma, Aarto (1976) New aspects to the geology of the Outokumpu region. Bull. Geol. Soc. Finland 48: 5-24.

Knopf, Adolf (1929) The Mother Lode system of California. U.S. Geol. Surv., Prof. Paper 157.

Mikkola, Erkki (1941) Explanation to the geological (bedrock) map, sheets B7-C7-D7; with map, 1937. General Geological Map of Finland, $1: 400000$.

Nenonen, Eero (1975) Report on the explorations in the surroundings of Riikonkoski, Kittilä (in Finnish). Unpubl. report, Geol. Surv. Finland.

Nenonen, Eero and Puustinen, Kauko (1976) Naakenavaara: Geochemistry of till and weathered rocks. Journ. Geochem. Expl. 5: 274-277.

Nurmi, A. (1975) Geochemical exploration in a glacial ice-divide region: Riikonkoski copper ore deposit, Kittilä, Finnish Lapland. Pp 5459 in Prospecting in areas of glaciated terrain; ed. by M. J. Jones, Inst. of Mining and Met.

Ohlson, Birger (1969) Bedrock and Quaternary deposits of the Loukinen basin in western Finnish Lapland. Fennia 90 (2) (1969-1971).

Paakkola, Juhani (1971) The volcanic complex and associated manganiferous iron formation of the Porkonen-Pahtavaara area in Finnish Lapland. Bull. Comm. Géol. Finlande 247.

Partridge, F. C. (1937) Note on the green micas of North-Eastern Transvaal. Trans. Geol. Soc. South Africa 39: 457-460.

Pekkala, Y. (1972) Report on the investigations concerning the chromian marbles in Kittilä in the year 1972 (in Finnish). Unpubl. report, Geol. Surv. Finland.

Piispanen, Risto (1972) On the spilitic rocks of the Karelidic Belt in western Kuusamo, northern Finland. Acta Univ. Ouluensis, Ser. A, Sci. Rerum Nat. 4, Geologica 2.

Pretorius, D. A. (1976) The nature of the Witwatersrand gold-uranium deposits. Pp. 29-88 in Handbook of strata-bound and stratiform ore deposits, vol. 7; ed. by K. H. Wolf. Elsevier Sci. Publ. Co., Amsterdam.

Ridler, R. H. (1970) Relationship of mineralization to volcanic stratigraphy in the KirklandLarder Lakes area, Ontario. Geol. Assoc. Canada, Proc. 21: 33-42.

Ridler, R. H. (1972) Volcanic stratigraphy of the Kirkland Lake area. Precambrian volcanism of the Noranda-Kirkland, Lake-Timmins, Michipicoten, and Mamainse Point areas, Quebec and Ontario. Ed. by A. M. Goodwin et al., Int. Geol. Congr., Quide Book A40-C40. $33-52$.

Ridler, R. H. (1976) Stratigraphic keys to the gold metallogeny of the Abitibi Belt. Can Mining J. 97: $81-90$.

Tihor, L. A. and Crocket, J. H. (1976) Origin and distribution of gold-bearing carbonate zones of the Kirkland Lake-Larder Lake area, Ontario. Geol.Surv. Canada, Paper 76-1 A: 407-408.

Tihor, L. A. and Crocket, J. H. (1977) Gold distribution in the Kirkland Lake-Larder Lake area, with emphasis on Kerr Addison-type ore deposits - A progress report. Geol. Surv. Canada, Paper 77-1 A: 363-369.

Tufar, Werner (1968) Fuchsit vom Puchegg bei Vorau (Oststeiermark). Tshermacks Min. Petr. Mitt. Bd. XII (2-3): 182-203.

White, D. E. and Waring, G. A. (1963) Volcanic emanations. U.S. Geol. Surv., Prof. Paper 440K: $1-29$.

Whitmore, D. R. E., Berry, L. G. and Hawley, J. E. (1946) Chrome micas. Am. Min. 31: 1-21.

Wolf, K. H., Chilinger, G. V. and Beales, F. W. (1967) Elemental composition of carbonate skeletons, minerals and sediments. Pp. 23150 in Carbonate rocks, Developments in sedimentology 9B; ed. by George F. Chilanger et al. Elsevier Publ. Co.

Yletyinen, Veijo and Nenonen, Eero (1972) Report on the explorations in Riikonkoski, Kittilä in the years 1969-1972 (in Finnish). Unpubl. report, Geol. Surv. Finland.

Manuscript received, October 21, 1977. 